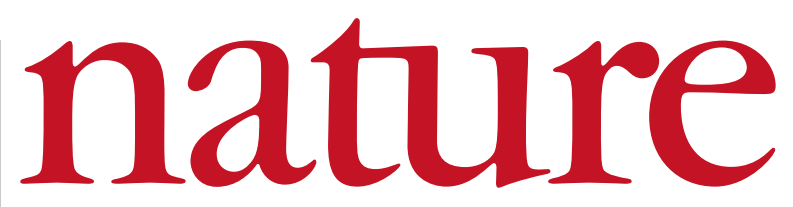

7 October 2004 Volume 431 Issue no 7009

\title{
Kyoto challenge has just begun
}

A move by Russia to support the Kyoto Protocol should usher in an era of international collaboration in mitigating climate change. Validating emissions trading and bringing developing economies into the fold are the next priorities.

$\mathrm{R}$ ussia's climate politics are something of a mystery to outsiders, but the Russian government has reportedly decided to ratify the Kyoto Protocol on climate change, and approval by the parliament should be a formality. Thus the last obstacle to the protocol's coming into force is set to be removed.

The decision is emerging in a way that lacks conviction from Russia's political and scientific élite (see Nature 431, 12-13; 2004), and the country's Kyoto sceptics can still delay matters. What is important, however, is that the first multilaterally binding climateprotection regime now seems certain to see the light of day.

Even more important is the need to tackle the treaty's limitations. The legal force behind some of its key rules - including penalties for countries emitting more greenhouse gases than they should - is questionable. And excess emitters have little to fear: compensation for emissions at a later date could be endlessly postponed.

Another penalty is suspension from emissions trading. But whether the creation of an international emissions market - essential to reduce the costs of implementing the protocol — will provide an efficient tool for reducing 'hot air' is yet to be seen. It will soon be tested in the European Union (EU), where emissions trading is set to begin in January. The EU's political leaders, who have pressed ahead despite reservations from large European industries, would be delighted if the Kyoto Protocol were to come into effect then.

\section{Futures of artificial life}

\section{Researchers involved in synthetic biology need to take steps to engage more with the public.}

n 1975, when genetic engineering was still young, the leaders in the field called a meeting at Asilomar, a seaside conference centre in California, where they thrashed out the possible environmental and health risks of the powerful new gene-splicing techniques that they were wielding. They not only agreed important containment guidelines for certain kinds of work, but achieved something potentially more valuable: the wide press coverage they received won the public's trust that scientists were behaving responsibly.

Today that trust is on shaky ground. Controversies over genetically engineered crops and embryo research are leading people to question how carefully scientists consider the possible consequences of their work before barrelling ahead. This is no small concern for science, as it has already led to restrictions.

At the same time, biologists have come to feel increasingly secure in the belief that some ecological nightmare is not likely to spring out of a graduate student's Petri dish. Every day for decades they have been transferring modified genes into microbes, nematodes and mice. At least some of the results - the errant fruitfly or the culture tube spilled in the sink - have no doubt escaped into the environment, without producing a biological Chernobyl.

Is that confidence in step with the technology? The tools now available to the molecular biologist have the potential to provide a stunning array of benefits, for both biomedicine and basic biology. Researchers are learning to understand and manipulate the genetic to foresee what the actual risks are.
Many details of the treaty still await clarification. But its true significance is its potential to establish confidence in the practicability of a complex international climate-protection agreement. In particular, Russia's participation will greatly increase the scope for buying and selling emissions rights, and for gaining credits for exporting 'clean development' technologies — key issues for European, Canadian and Japanese industries concerned about the fairness and liquidity of the international emissions market. Whether emissions can be checked against permitted levels remains a key technical challenge.

Russia's ratification should provide a push towards future climate negotiations, and may even prompt the next US administration to take a constructive role. And the authority and credibility of the International Panel on Climate Change can only benefit as well.

The problem of global warming is here to stay, however. Fossil fuels still account for some $90 \%$ of the world's energy consumption and are still in abundant supply. Hundreds of millions of people in poorer countries have more spending power, and their consumption is surging, pushing up their energy demand. Any emissions control strategy is therefore ultimately doomed to fail without the inclusion of tomorrow's mega-economies, which are exempted from the need to cut emissions from 1990 levels. Russia's wobbly goodwill provides a glimmer of hope, but our planet's future climate will be determined, above all, in China and India.

circuits that control cells. They can transfer entire synthetic pathways to bacteria to make drugs that must otherwise be extracted from rare plants at great cost. Viral genomes can be synthesized chemically in weeks, and bacterial genomes will soon be within reach.

Through such technologies, a new field of synthetic biology is emerging (see page 624). Bacteria and yeast have been engineered to build proteins impossible in nature, and with novel properties, by the addition of synthetic amino acids. Several groups are even working on assembling simple cells from basic components. This is no longer a matter just of moving genes around. This is shaping life like clay.

Members of the synthetic-biology community have begun to discuss the possible risks, and ethical implications, of their work. But there is no plan as yet for anything like another Asilomar. In one sense, it may be too soon. The scope of these tools is much broader than that of recombinant DNA, and it is certain to be more difficult

But perhaps such discussions can't come soon enough. What will happen if biologists announce that they have made the first living cells from scratch without having demonstrated to the public any concern for the implications? Researchers must do more than talk among themselves. They must demonstrate publicly that they are willing to consult and reflect carefully about risk — both perceived and genuine - and to moderate their actions accordingly. The need for public trust, significant in 1975 , is all the greater today. 